Research article

urn:1sid:zoobank.org:pub:57A119FB-D865-4646-8EB0-EEBD54F3E3FE

\title{
Four new species of Nyctonympha Thomson, 1868 (Coleoptera, Cerambycidae, Lamiinae)
}

\author{
Antonio SANTOS-SILVA ${ }^{1}$ \& Juan Pablo BOTERO ${ }^{2, *}$ \\ ${ }^{1}$ Museu de Zoologia, Universidade de São Paulo, \\ Caixa Postal 42.494, 04218-970, São Paulo, SP, Brazil. \\ ${ }^{2}$ Departamento de Entomologia, Museu Nacional, Universidade Federal do Rio de Janeiro, \\ Quinta da Boa Vista, São Cristóvão, CEP 20940-040, Rio de Janeiro, RJ, Brazil. \\ *Corresponding author: jp bot@yahoo.com \\ ${ }^{1}$ Email: toncriss@uol.com.br \\ ${ }^{1}$ urn:1sid:zoobank.org:author:E71CB0BE-4876-4B0B-ACAF-5AE13BA81E7E \\ ${ }^{2}$ urn:1sid:zoobank.org:author:463CA17F-AC2C-44DF-85AB-2AEA79684A12
}

\begin{abstract}
Four new species of Nyctonympha Thomson, 1868 are described: N. antonkozlovi sp. nov. and $N$. sinjaevi sp. nov. from Colombia, $N$. birai sp. nov. from Venezuela and $N$. mariahelenae sp. nov. from Brazil (Rondônia), Bolivia and Peru. Nyctonympha flavipes Aurivillius, 1990 is formally excluded from the Peruvian and Brazilian fauna. A provisional key to species of Nyctonympha is provided.
\end{abstract}

Keywords. Forsteriini, Neotropical region, South America, taxonomy.

Santos-Silva A. \& Botero J.P. 2017. Four new species of Nyctonympha Thomson, 1868 (Coleoptera, Cerambycidae, Lamiinae). European Journal of Taxonomy 332: 1-16. https://doi.org/10.5852/ejt.2017.332

\section{Introduction}

Thomson (1868) established Nyctonympha for his new species N. cribrata from Colombia. Later, Lameere (1893) described two species from Venezuela and assigned them to Hebestola Haldeman, 1847: H. carcharias Lameere, 1893 and H. costipennis Lameere, 1893. A few years later, Belon (1897) described another species from Bolivia, also in Hebestola: H. annulipes Belon, 1897. Aurivillius (1900, 1920) described two new species from Venezuela in Nyctonympha: N. glauca Aurivillius, 1900 and N. annulata Aurivillius, 1900, and one more from Bolivia: N. flavipes Aurivillius, 1920.

Martins \& Galileo (1989) synonymized $N$. glauca with $H$. carcharias, transferring the latter along with H. costipennis to Nyctonympha Thomson, 1868. According to these authors, the holotype of $H$. costipennis was not found in any collection and the transfer was based on the original description, but with some doubts. They examined the holotype of Hebestola carcharias, but they did not mention whether they examined the holotype of N. glauca. In the same work, they described N. punctata Martins \& Galileo, 1989 from Argentina and provided a key to species of Nyctonympha. We also tried to locate the holotype of Hebestola costipennis, but without success. 
Later, Martins \& Galileo (1992) described N. andersoni and N. howdenarum from Colombia, and $N$. taeniata from Trinidad and Tobago. A new key to species of the genus was also provided. After recording N. flavipes from Brazil (Martins \& Galileo 1989), the same authors went on to describe the second Nyctonympha species known from Brazil: N. carioca (Galileo \& Martins 2001). Finally, Martins \& Galileo (2008) described N. affinis from French Guiana, and Galileo \& Martins (2008) described $N$. boyacana from Colombia.

Currently, Nyctonympha includes 14 species distributed in Central and South America (Monné \& Hovore 2006; Monné 2016). In the present paper, four new species are described: two from Colombia, one from Venezuela, and one from Brazil (Rondônia), Bolivia and Peru.

Aurivillius (1920) was the first author to provide a key to species of Nyctonympha. However, this key includes two species currently placed in Obereoides Fisher, 1938. Furthermore, the author separated N. cribrata Thomson, 1868 from the other species known at that time by the color of the antennomeres: unicolorous in N. cribrata; bicolorous in N. flavipes, N. glauca and N. annulata. Actually, the antennomeres of the holotype of N. cribrata are basally ringed with light color (at least on some antennomeres, Fig. 24).

Later, Martins \& Galileo $(1989,1992)$ provided the second and the third key to species of Nyctonympha. In these works, $N$. annulata and $N$. flavipes were incorrectly identified by the authors. In both keys, $N$. annulata was defined as having the elytral apex with a short spine at the outer angle. Actually, the outer apical angle of the elytra in the type specimens of $N$. annulata (Fig. 16) is not much different from that in N. carcharias (Fig. 17) or N. annulipes, and thus, it cannot be defined as having a short spine. Furthermore, the true $N$. annulata is distinctly more slender than $N$. annulata sensu Martins \& Galileo $(1989,1992)$. The latter is described here as $N$. birai sp. nov.

Additionally, in the key by Martins \& Galileo (1989), N. flavipes, is defined as having a short and thick spine at the outer angle. However, the holotype (Fig. 20) has the outer angle of the elytra distinctly projected and elongate. In the key by Martins \& Galileo (1992), the shape of the elytral spine of $N$. flavipes was not defined. We believe that in both works the same specimens were studied, which are deposited at MZSP and MNRJ (part of the specimens, originally belonging to MNRJ, were retained by the MZSP collection). Actually, using the key by Martins \& Galileo (1992), N. flavipes sensu Martins \& Galileo (1992) cannot be separated from the true N. flavipes or N. flavipes sensu Martins \& Galileo (1989). The true $N$. flavipes, besides the different elytral apex, is distinctly more slender than $N$. flavipes sensu Martins \& Galileo $(1989,1992)$, and has the pronotal and elytral punctation distinctly coarser and denser. The latter is also described here as a new species: N. mariahelenae sp. nov.

The synonymy between $N$. carcharias and $N$. glauca proposed by Martins \& Galileo (1989) appears correct, although the elytral apex is somewhat different (mainly the outer angle). Unfortunately, the photographs of the holotype of $N$. carcharias do not show any details such as the sculpture of the mesepisternum (a feature not mentioned in the original description). Apparently, the specimen studied by Martins \& Galileo $(1989,1992)$, deposited at the MZSP, agrees well with the original description and photographs of the holotype of $N$. carcharias.

Martins \& Galileo (1989) examined the holotype of N. cribrata, and the specimen deposited at MZSP, identified as being of this species, agrees very well with it.

We provide a provisional key to species of Nyctonympha, because details of some species are unknown to us, mainly the ventral side of the body. 


\title{
Material and methods
}

Photographs were taken with a Canon EOS Rebel T3i DSLR camera, Canon MP-E $65 \mathrm{~mm}$ f/2.8 1-5× macro lens, controlled by Zerene Stacker AutoMontage software. Measurements were taken in 'mm' using a micrometer ocular Hensoldt / Wetzlar - Mess 10 in the Leica MZ6 stereo microscope (also used in the study of specimens).

The acronyms used in the text are as follows:

DZUP = Coleção de Entomologia Pe. Jesus Santiago Moure, Departamento deZoologia, Universidade Federal do Paraná, Curitiba, Brazil

IRSNB = Institut Royal des Sciences Naturelles de Belgique, Brussels, Belgium

MNRJ = Museu Nacional, Universidade Federal do Rio de Janeiro, Rio de Janeiro, Brazil

MSZP $=$ Museu de Zoologia, Universidade de São Paulo, Brazil

\section{Results}

\author{
Class Hexapoda Blainville, 1816 \\ Order Coleoptera Linnaeus, 1758 \\ Suborder Polyphaga Emery, 1886 \\ Superfamily Chrysomeloidea Latreille, 1802 \\ Family Cerambycidae Latreille, 1802 \\ Subfamily Lamiinae Latreille, 1825 \\ Tribe Forsteriini Tippmann, 1960 \\ Genus Nyctonympha Thomson, 1868 \\ Nyctonympha sinjaevi sp. nov. \\ urn:Isid:zoobank.org:act:814134AA-C411-403F-80B5-145ED7BD6827
}

Figs $1-4$

\section{Differential diagnosis}

Depending on the angle of light, most of the pubescence appears distinctly golden or somewhat greenish.

Nyctonympha sinjaevi sp. nov. differs from N. cribrata Thomson, 1868 as follows: body wider; distance between antennal tubercles wider; distance between upper eye lobes smaller (slightly wider than 1.5 times width of one lobe); distal antennomeres more slender and longer; pronotal and elytral punctation finer (distinctly sparser on pronotum); sutural elytral apex rounded. In N. cribrata (see photograph of the holotype in Bezark 2016) the body is slender, the distance between antennal tubercles is narrower, the distance between upper eye lobes is larger (distinctly wider than 1.5 times width of one lobe), the distal antennomeres are thicker and shorter, the pronotal and elytral punctation is coarser (distinctly denser on pronotum), and the sutural elytral apex is projected.

\section{Etymology}

The specific epithet refers to Victor Sinjaev, one of the collectors of the holotype.

\section{Type material}

\section{Holotype}

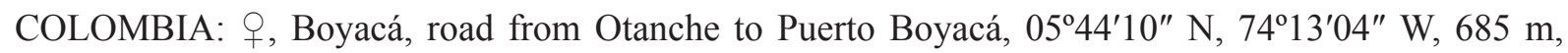
10-16 Feb. 2016, V. Sinjaev and V. Zaritzki leg. (MZSP). 


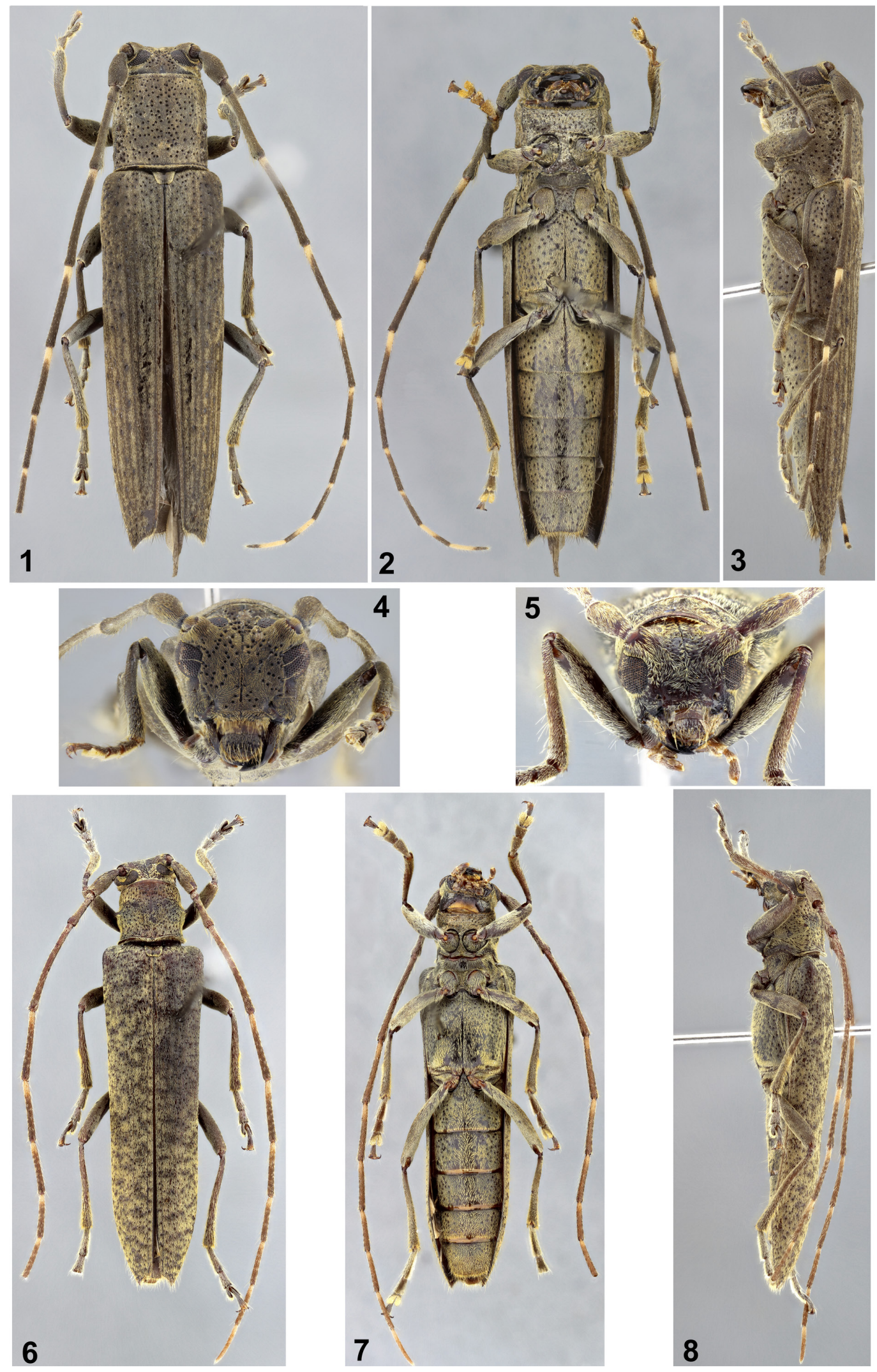

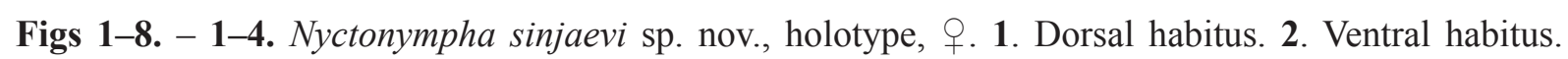
3. Lateral habitus. 4. Head, frontal view. - 5-8. Nyctonympha antonkozlovi sp. nov., holotype, ठ̊. 5. Head, frontal view. 6. Dorsal habitus. 7. Ventral habitus. 8. Lateral habitus. 


\section{Description}

Dimensions (mm). Total length: 15.50; prothoracic length: 2.90; anterior prothoracic width: 2.75 ; posterior prothoracic width: 2.90; widest prothoracic width: 3.00; humeral width: 3.70; elytral length: 11.60.

\section{Female}

Integument dark-brown, almost black; mouthparts reddish-brown except palpi brown with only basal and distal areas reddish-brown; base of antennomeres IV-IX yellowish (this area larger ventrally on IV-VI, mainly on IV); antennomere X yellowish on basal half (this area slightly longer ventrally); antennomere XI yellowish on basal $2 / 3$.

HEAD. Frons (Fig. 4) coarsely, sparsely punctate; with abundant, very short, yellowish-ochraceous pubescence (more golden depending on angle of light), not obscuring integument, interspersed with long, erect, sparse, yellowish setae laterally. Area between antennal tubercles and middle of upper eye lobes slightly depressed centrally, moderately finely and abundantly punctate (punctures as on frons); pubescence as on frons centrally, slightly longer and more yellowish close to eyes. Remaining surface of vertex finely, sparsely punctate, mainly centrally; pubescence as on frons. Area behind upper eye lobes with band of yellowish pubescence close to eye (widened toward lower eye lobe), shorter, yellowishochraceous close to prothorax; with moderately long, erect, yellowish setae close to eye. Area behind lower eye lobe distinctly depressed close to prothoracic margin; moderately finely, abundantly punctate close to eye; with yellowish pubescence, not obscuring integument. Genae with punctures as on frons, sparser toward frons, smooth toward apex; with yellowish pubescence toward ventral side, shorter, yellowish-ochraceous toward frons. Antennal tubercles with pubescence as on frons, but slightly denser; punctures as on frons on frontal base, absent on remaining surface. Coronal suture distinct from clypeus to prothorax. Submentum with short, yellowish pubescence. Postclypeus with yellowish pubescence, interspersed with long, yellowish setae directed forward. Labrum convex, finely and moderately abundantly punctate; with short, moderately sparse, decumbent, yellowish setae interspersed with long, erect, yellowish setae directed forward, distinctly more abundant toward apex. Mandibles longitudinally sulcate on basal half (sulcus narrowed toward apex); with short, decumbent, yellow setae on basal half, distinctly more abundant basally, interspersed with long, erect, yellowish, sparse setae; distal half glabrous. Distance between upper eye lobes 0.45 times length of scape; distance between lower eye lobes in frontal view 1.25 times length of scape. Antennae 1.6 times elytral length, reaching elytral apex before middle of antennomere IX. Antennal segments with short, decumbent, yellowish pubescence, not obscuring integument; scape clavate, distinctly enlarged on inner side after basal quarter; antennomeres III-XI with short, erect, sparse, yellowish setae dorsally, gradually, more abundant toward distal segments; antennomeres III-XI with long, erect, yellowish setae ventrally (distinctly shorter, sparser toward distal segments); antennal formula (ratio) based on antennomere III: scape $=0.62$; pedicel $=$ $0.18 ; \mathrm{IV}=1.41 ; \mathrm{V}=1.19 ; \mathrm{VI}=0.98 ; \mathrm{VII}=0.73 ; \mathrm{VIII}=0.62 ; \mathrm{IX}=0.54 ; \mathrm{X}=0.52 ; \mathrm{XI}=0.60$.

Thorax. Prothorax cylindrical, slightly wider than long (1.05 times), moderately finely and sparsely punctate on sides and pronotum (punctures similar in size to those on frons); sides sub-parallel, with transverse gibbosity near distal margin at area closer to pronotum; with short, decumbent, yellowishochraceous pubescence (more yellowish on some areas), not obscuring integument, interspersed with long, erect, sparse, yellowish setae. Pronotum centrally with feebly elevated, narrow, longitudinal carina; sides with small, blunt tubercle placed slightly before middle; with short, decumbent, abundant, yellowish-ochraceous pubescence, not obscuring integument, more yellowish, basally and laterally. Prosternum moderately finely punctate, slightly more abundant laterally; with short, decumbent, abundant yellowish pubescence, not obscuring integument. Prosternal process moderately finely, abundantly punctate; with short, sub-erect, abundant, yellowish setae. Mesosternum distinctly depressed on wider central area; finely, shallowly and sparsely punctate on depressed region, smooth laterally; with short, decumbent, yellowish-ochraceous pubescence not obscuring integument. Mesosternal 
process moderately finely, sparsely punctate (punctures as on pronotum); with yellowish-ochraceous pubescence (except glabrous distal lobes) interspersed with long, erect, yellowish setae; apex distinctly emarginate centrally, laterally with small, but distinct lobe. Mesepisternum moderately finely and abundantly punctate; with decumbent, abundant, yellowish pubescence, partially obscuring integument. Mesepimeron finely, sparsely punctate (punctures slightly finer), shallower than on mesepisternum; pubescence as on mesepisternum. Metepisternum finely, sparsely punctate; with yellowish-ochraceous pubescence. Metasternum coarsely, moderately sparsely punctate; with, short, abundant, yellowish pubescence, partially obscuring integument (mainly laterally), interspersed with long, erect, sparse, yellowish setae. Scutellum with yellow pubescence, except on narrow, longitudinal, glabrous area.

ELYTRA. Moderately finely, abundantly punctate on basal third (coarser laterally), gradually finer, sparser toward apex; very finely, longitudinally sulcate; with abundant, yellowish pubescence on each area between sulci, somewhat sparser inside of sulci; apex strongly obliquely truncate (slightly concave; with small projection near sutural angle on right elytron), making outer angle distinctly projected, with sutural angle rounded.

LEGS. Femora with yellowish pubescence, not obscuring integument, except glabrous areas surrounding each fine, sparse puncture (less distinct on metafemora).

AвDOMEN. With yellowish pubescence, not obscuring integument (more yellowish laterally), except on glabrous areas surrounding each fine, sparse puncture (more abundant laterally); ventrite $\mathrm{V}$ with central longitudinal groove, widened from base to apex; apex of ventrite $\mathrm{V}$ truncate, slightly widely emarginate centrally.

\section{Male}

Unknown.

Nyctonympha antonkozlovi sp. nov. urn:1sid:zoobank.org:act:A0EC0502-F0A5-4F57-88A7-4DBECDA1D899

Figs 5-8

\section{Differential diagnosis}

Nyctonympha antonkozlovi sp. nov. differs from N. boyacana Martins \& Galileo, 2008 (see photograph of the holotype in Bezark 2016) by: the scape, pronotum and elytra distinctly less punctate (mainly scape); femora without punctures surrounded by glabrous area; mesepisternum impunctate. In $N$. boyacana the scape, pronotum and elytra are distinctly more densely punctate, the femora have punctures surrounded by glabrous areas, and the mesepisternum is punctate. The new species differs from $N$. howdenarum Martins \& Galileo, 1992 by the wider body, by the distance between upper eye lobes distinctly wider than width of one lobe, by the prothorax wider than long, and by the pronotum with gibbosities. In $N$. howdenarum the body is slender, the distance between upper eye lobes is about equal to width of one lobe, the prothorax is about as long as wide (including lateral tubercles), and the pronotum has no gibbosities.

\section{Etymology}

The specific epithet refers to Anton Olegovich Kozlov, who sent and donated the holotype.

\section{Type material}

Holotype

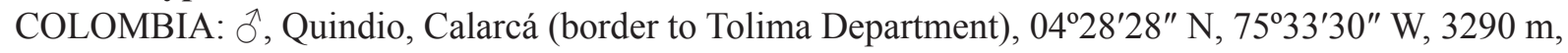
23-24 Mar. 2015, V. Sinjaev leg. (MZSP). 


\section{Description}

Dimensions (mm). Total length: 15.10; prothoracic length: 2.10; anterior prothoracic width: 2.05; posterior prothoracic width: 2.40; widest prothoracic width (between apices of lateral tubercles): 2.65; humeral width: 3.50 ; elytral length: 11.80 .

\section{Male}

Integument dark-brown; mouthparts reddish-brown except palpi brown with only basal and distal areas reddish-brown; antennomeres V-XI yellowish ringed on base; antennomeres gradually lighter toward distal segments, mainly after VIII; gula yellowish-brown on base, gradually dark-brown toward submentum; distal area of ventrites I-IV narrowly, transversely reddish-brown.

HEAD. Frons finely, sparsely punctate (Fig. 5), mainly toward clypeus; with short, decumbent, ochraceous setae, distinctly not obscuring integument, sparser toward clypeus, mainly laterally; with some long, erect, yellowish setae close to eyes. With narrow band of yellowish setae surrounding eyes. Area between antennal tubercles finely, sparsely punctate, mainly toward center; with short, decumbent, moderately sparse, ochraceous setae. Remaining surface of vertex finely, abundantly punctate; with short, abundant, yellowish setae, partially obscuring integument (distinctly longer than on frons); with some long, erect, yellowish setae close to eyes. Tempora with short, abundant, yellowish setae, interspersed with some long, erect, yellowish setae near lower eye lobes (area closer to prothorax glabrous behind lower eye lobes). Genae with short, decumbent, ochraceous setae toward apex (distinctly shorter and finer than yellowish band), sparser toward dorsal side. Antennal tubercles finely, sparsely punctate on base; with ochraceous pubescence on base, gradually yellowish toward apex. Coronal suture slightly distinct from clypeus to middle of frons, distinct from this area to prothoracic margin. Postclypeus with short, sparse, ochraceous setae except glabrous lateral area. Labrum concave, coplanar with anteclypeus on basal half, sloped on distal half; finely, sparsely punctate on base of coplanar area, denser about middle, sparser toward apex; with moderately sparse, ochraceous setae, interspersed with long, erect, yellowish setae mainly laterally after middle. Mandibles with triangular depression on basal half; with short, abundant, yellowish setae inside depression, glabrous on remaining surface. Distance between upper eye lobes 0.45 times length of scape; distance between lower eye lobes in frontal view 0.90 times length of scape. Antennae 1.6 times elytral length, reaching elytral apex at basal quarter of antennomere IX; antennal segments with ochraceous pubescence, not obscuring integument; scape gradually enlarged toward base of distal third, then slightly narrowed toward apex, with long, erect, yellowish setae ventrally near apex; antennomeres III-XI with moderately long, erect, yellowish setae ventrally, gradually shorter and sparser toward distal segments; antennal formula (ratio) based on antennomere III: scape $=1.15$; pedicel $=0.22 ; \mathrm{IV}=2.70 ; \mathrm{V}=2.00 ; \mathrm{VI}=1.74 ; \mathrm{VII}=1.59 ; \mathrm{VIII}=1.29 ; \mathrm{IX}=1.27 ; \mathrm{X}=1.18 ; \mathrm{XI}=1.18$.

Thorax. Prothorax wider than long (1.2 times); sides concave between base and lateral tubercle and slightly concave between lateral tubercle and distal margin; finely, sparsely punctate below lateral tubercle, gradually sparser centrally toward ventral side, densely basally toward prosternal process; with ochraceous pubescence, partially obscuring integument, distinctly sparser basally. Pronotum transversely sulcate near base and apex (less so centrally); sides with conical, moderately acute tubercle placed about middle; with three distinct gibbosities: one at each side of anterior half, close to middle of pronotum, transverse, slightly oblique, and one centrally, elongate, more elevated than lateral gibbosities, narrowed toward distal area of pronotum; surface finely, moderately abundantly punctate (punctures slightly coarser than on sides of prothorax), smooth on part of central gibbosity; with ochraceous pubescence, partially obscuring integument, except glabrous top of central gibbosity. Prosternum finely, moderately abundantly punctate (punctures as on sides of prothorax); with ochraceous pubescence, partially obscuring integument. Prosternal process without distinct punctures; with ochraceous pubescence obscuring part of integument. Mesosternum depressed on wider central area; finely, sparsely punctate on depressed region, smooth laterally; with ochraceous pubescence not obscuring 
integument, more distinct laterally. Mesepisternum and mesepimeron impunctate; with ochraceous pubescence, partially obscuring integument. Mesosternal process deeply emarginate at apex, laterally forming acute lobe at each side. Metepisternum finely, sparsely punctate; with ochraceous pubescence partially obscuring integument. Metasternum coarsely, moderately abundantly punctate laterally; with ochraceous pubescence not obscuring integument (obscuring integument on area near metacoxae); with long, erect, sparse, yellowish setae. Scutellum slightly depressed centrally on basal $2 / 3$, truncate at apex; with ochraceous pubescence not obscuring integument.

ELYTRA. Surface somewhat irregular; finely, moderately abundantly punctate on basal half, gradually sparser toward apex, interspersed with coarse punctures; with ochraceous, dense pubescence interspersed with several irregular areas with sparser pubescence; with erect, sparse, yellowish setae on distal quarter (longer, more abundant laterally and toward apex); apex obliquely truncate, with outer angle distinctly spined and sutural angle rounded.

LEGS. Femora with ochraceous pubescence, not obscuring integument; without punctures surrounded by glabrous areas.

ABDOMEN. Ventrites finely, moderately abundantly punctate laterally, gradually finer, sparser toward center; with ochraceous pubescence not obscuring integument, interspersed with long, erect, yellowish setae; apex of ventrite $\mathrm{V}$ rounded, centrally emarginate.

Nyctonympha birai sp. nov. urn:1sid:zoobank.org:act:22F0FD91-62C1-4851-B6B7-2CFCDBD13C64

Figs 9-11

Nyctonympha annulata Martins \& Galileo, 1989: 124 (key), 125.

Nyctonympha annulata - Martins \& Galileo 1992: 103 (key), misidentification.

\section{Differential diagnosis}

Nyctonympha birai sp. nov. differs from N. annulata Aurivillius, 1990 by: the wider body; prothorax without lateral tubercles, as wide as long; elytral apex slightly projected at outer angle, and slightly obliquely truncate. In N. annulata (Fig. 16), the body is slender, the prothorax is longer than wide, and the elytral apex has a long spine at outer angle and is strongly obliquely truncate.

\section{Etymology}

The specific epithet refers to the late Ubirajara Ribeiro Martins de Souza (Bira).

\section{Type material}

\section{Holotype}

VENEZUELA: + , Distrito Capital, Caracas (Rio Caurimare), 29 Jun. 1959, Bordon leg. (MZSP).

\section{Paratypes}

VENEZUELA: 1 q, Distrito Capital, Caracas (Rio Caurimare), 26 Jan. 1964, Bordon leg. (MNRJ); 1 ðૈ, Miranda, San Antonio de los Altos, 1400 m (no date or collector indicated) (MNRJ); 1 , 9 Nov. 1963,

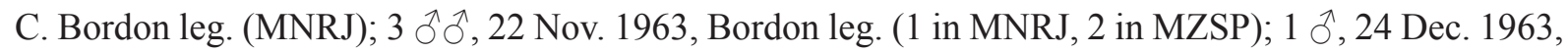
Bordon leg. (MZSP); 1 , 15 Apr. 1964, Bordon leg. (MNRJ). 

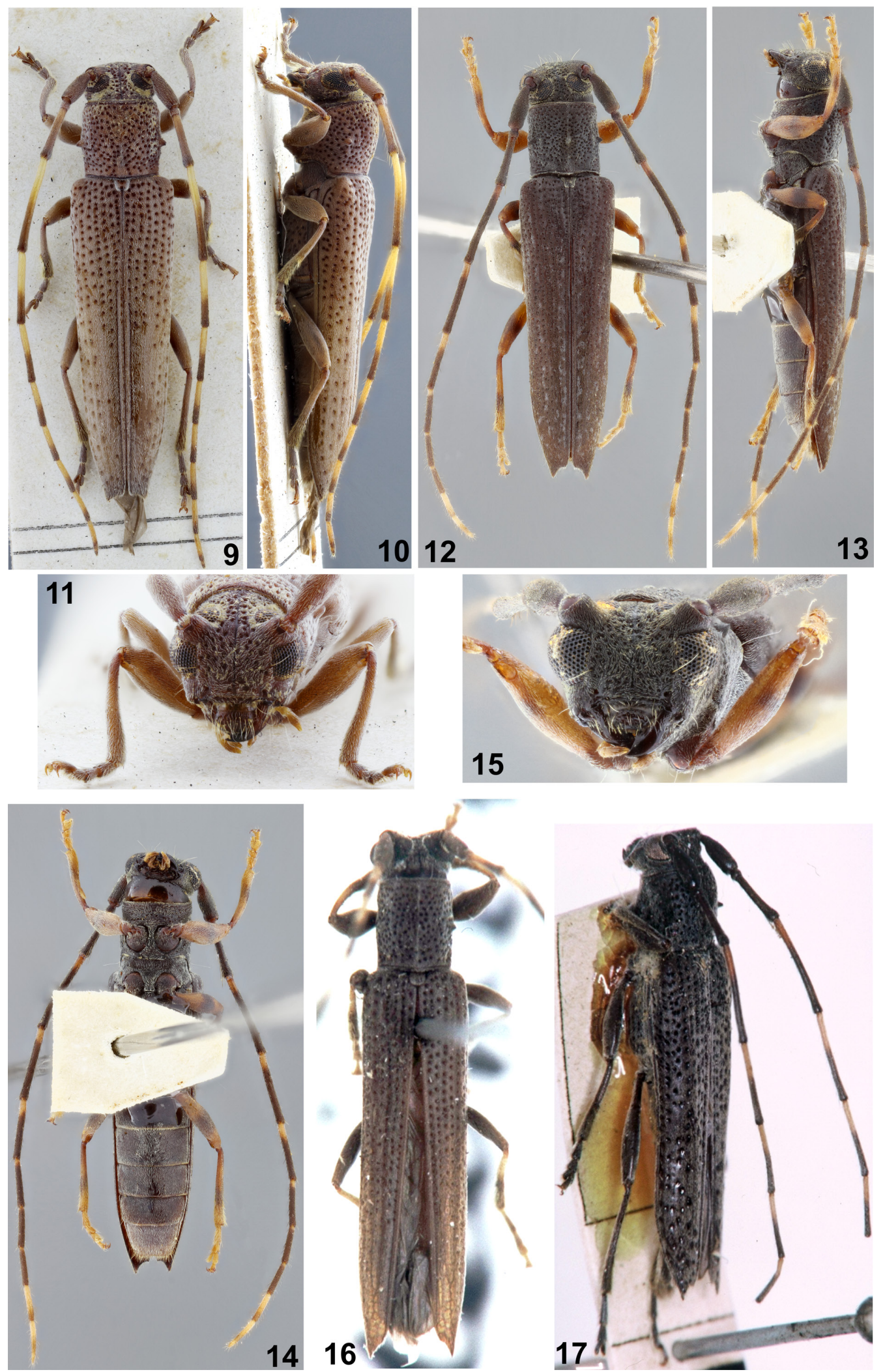

3

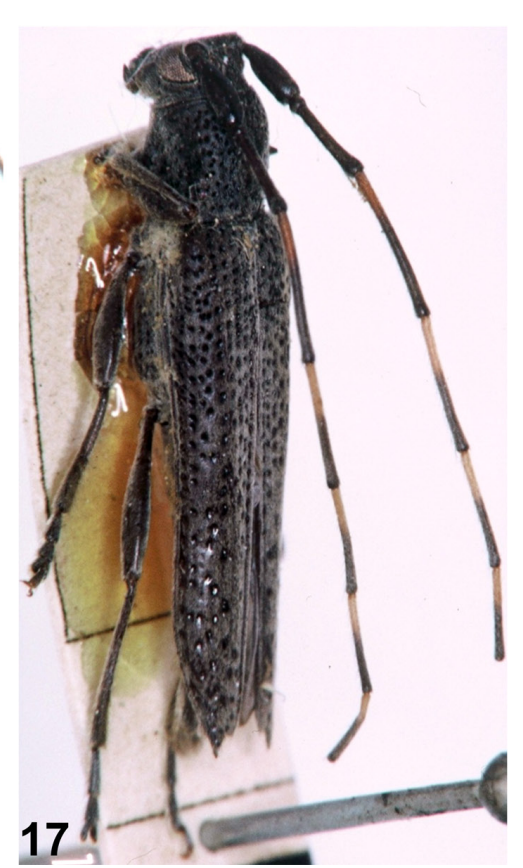

Figs 9-17. - 9-11. Nyctonympha birai sp. nov., holotype, ‥ 9. Dorsal habitus. 10. Lateral habitus. 11. Head, frontal view. - 12-15. Nyctonympha mariahelenae sp. nov., holotype, $q$. 12. Dorsal habitus. 13. Lateral habitus. 14. Ventral habitus. 15. Head, frontal view. - 16. Nyctonympha annulata Aurivillius, 1900, syntype, dorsal habitus. - 17. Nyctonympha carcharias Lameere, 1893, holotype, lateral view. 


\section{Description}

Dimensions (mm). Holotype female/paratypes male /paratypes female. Total length: 10.55/7.68.4/7.90-9.65; prothoracic length: 1.85/1.3-1.4/1.35-1.65; anterior prothoracic width: $1.65 / 1.2-$ 1.3/1.20-1.50; posterior prothoracic width: 1.80/1.1-1.2/1.25-1.60; widest prothoracic width (between apices of lateral tubercles): 2.10/1.3-1.4/1.55-1.85; humeral width: 2.45/1.7-1.8/1.75-2.15; elytral length: 7.90/5.7-6.3/5.95-7.40.

\section{Female}

Head dark-brown, reddish-brown on some areas; mouthparts reddish-brown; scape dark-brown, maculate with reddish-brown on some areas; antennomere III reddish-brown on base, gradually darkbrown toward apex; antennomeres IV-VII yellowish on basal half, gradually dark-brown toward apex; antennomeres VIII-XI yellowish on basal $2 / 3$, dark-brown on distal third; prothorax dark reddish-brown, slightly lighter on some areas; ventral side of meso- and metathorax and abdomen dark-brown (reddishbrown on ventrite $\mathrm{V}$ ); elytra pale reddish-brown, slightly darkened close to apex; femora reddish-brown, more brownish on some areas; tibiae dark reddish-brown on basal half, dark-brown on distal half. Pubescence grayish-white, not obscuring integument.

HEAD. Frons moderately coarsely, sparsely punctate (punctures slightly denser toward antennal tubercles); with some long, erect, yellowish setae close to lower eye lobes. Area between antennal tubercles with punctures as on frons, more abundant laterally. Area between upper eye lobes coarsely, abundantly punctate (punctures coarser than on frons). Remaining surface of vertex moderately coarsely (punctures slightly finer than on area between upper eye lobes), sparsely punctate (sparser centrally toward prothorax). Tempora moderately coarsely, sparsely punctate behind upper eye lobes (punctures as on area of vertex closer to prothorax); area behind lower eye lobe tumid close to eye, with row of moderately coarse punctures. Genae impunctate, with some long, erect, yellowish setae ventrally. Antennal tubercles impunctate. Coronal suture distinct from clypeus to prothoracic margin. Postclypeus glabrous laterally, with one long, erect, yellowish seta near glabrous area. Labrum concave, coplanar with anteclypeus on basal half, sloped on distal half; finely, abundantly punctate, mainly on coplanar region; with long, yellowish setae directed forward, mainly on sloped area. Mandibles with triangular depression on basal third; with long, sparse, erect, yellowish setae on basal half, glabrous on distal half. Distance between upper eye lobes 0.5 times length of scape; distance between lower eye lobes in frontal view equal to length of scape. Antennae 1.65 times elytral length, reaching elytral apex at basal quarter of antennomere IX; scape gradually enlarged on basal half (mainly at inner side), slightly narrowed toward apex on inner side of distal half; ventral side of scape, pedicel and antennomeres with erect, brownish setae ventrally, more abundant on III, gradually shorter, sparser toward distal segments; antennal formula (ratio) based on antennomere III: scape $=0.78$; pedicel $=0.14 ; \mathrm{IV}=1.72 ; \mathrm{V}=1.33$; $\mathrm{VI}=1.10 ; \mathrm{VII}=0.91 ; \mathrm{VIII}=0.76 ; \mathrm{IX}=0.71 ; \mathrm{X}=0.62 ; \mathrm{XI}=0.58$.

THORAx. Prothorax, excluding lateral tubercles, as long as wide; sides with small, conical tubercle slightly before middle, with blunt apex; surface coarsely, moderately sparsely punctate. Pronotum centrally with gibbosity slightly elevated on base, followed by slightly elevated carina; surface coarsely, abundantly punctate. Prosternum coarsely, sparsely punctate. Mesosternum, mesepisternum and metepisternum impunctate. Metasternum coarsely, moderately sparsely punctate, mainly toward center. Scutellum centrally depressed and glabrous.

ElYTRA. Coarsely, abundantly punctate on basal half (punctures aligned in rows), distinctly sparser on distal half, mainly toward suture; apex slightly obliquely truncate (slightly concave), with outer angle forming short tooth.

Legs. Meso- and metatibiae with moderately short, erect, abundant, yellowish setae on distal third. 
ABDOMEN. Ventrites impunctate.

\section{Variability}

Antennomere III dark reddish-brown on basal 2/3, dark-brown on distal third; antennomeres IV-XI yellowish, abruptly dark-brown near apex; prothorax brown, dark-reddish brown on some areas.

Nyctonympha mariahelenae sp. nov. urn:Isid:zoobank.org:act:EEBCE322-F82D-401D-BF55-5A3F96D2F574

Figs $12-15$

Nyctonympha flavipes Martins \& Galileo, 1989: 124 (key), 126.

Nyctonympha flavipes - Martins \& Galileo 1992: 103 (key), misidentification.

\section{Differential diagnosis}

Martins \& Galileo (1989) discussed N. flavipes (translated): "Species very close to N. annulipes. The elytral apex in $N$. flavipes is unarmed or very slightly projected at sutural angle, and the outer spine is wide, relatively short; the femora and tibiae are yellowish with a central brownish ring. That same color was mentioned by Belon (1897) in the description of $N$. annulipes. The identification of Belon's species was only possible via the examination of two syntypes (besides 15 other syntypes not examined, MNHN). The designation of the lectotype for $N$. annulipes would be very desirable because, perhaps, the type series is a composite." Nyctonympha mariahelenae sp. nov. differs from $N$. flavipes as follows: body wider; prothorax as wide as long; elytral punctures finer, less dense, mainly on distal half near suture; elytral apex less obliquely truncate, with outer angle shorter. In N. flavipes (Fig. 20) the body is slender, the prothorax (without lateral tubercles) is longer than wide, the elytral punctures are coarse, more abundant, including on distal half near suture, and the elytral apex is distinctly more oblique, with the spine of outer angle distinctly longer.

\section{Etymology}

The specific epithet refers to Maria Helena M. Galileo for her contribution to our knowledge of Cerambycidae from the Neotropical region.

\section{Type material}

\section{Holotype}

BRAZIL: + , Rondônia, Ouro Preto do Oeste, Nov. 1983, Becker, Roppa and Silva leg. (MNRJ).

\section{Paratypes}

BRAZIL: 1 ㄱ, same data as holotype (MZSP); 1 , same data as holotype, except Oct. 1983 (MZSP); 2 ふోَ̄, 1 + , Rondônia, Ouro Preto do Oeste, Oct. 1983, O. Roppa, J. Becker and B. Silva leg. (MNRJ);

1 , , Dec. 1983, B. Silva leg. (MNRJ).

BOLIVIA: 1 온 Santa Cruz, 4-6 km SSE of Buena Vista, Flora \& Fauna Hotel, 15-28 Feb. 2003, R. Clarke leg. (MZSP).

PERU: 1 क Arequipa, Hacienda Callanga, (no date or collector indicated) (MZSP); $1 \lesssim$ Junin, Chanchamayo, 20 Mar. 1949, Zellibor leg. (MNRJ); 1 q, Satipo, 1938 (MNRJ).

\section{Description}

Dimensions (mm). Holotype female/paratype males/paratype females). Total length: 8.80/7.9-8.1/9.1510.05; prothoracic length: 1.55/1.4-1.5/1.70-1.80; anterior prothoracic width: $1.45 / 1.3-1.4 / 1.55-1.60$; 
posterior prothoracic width: 1.50/1.2-1.3/1.55-1.65; widest prothoracic width (between apices of lateral tubercles): 1.60/1.40-1.60/1.70-1.85; humeral width: 2.00/1.70-1.80/2.05-2.30; elytral length: $6.45 / 5.80-5.90 / 6.65-7.35$.

\section{Female}

Integument dark-brown; mouthparts reddish-brown; ventral side of head brownish toward prothorax; antennomeres IV with wide, dark reddish-brown ring at base; antennomere V-VI with wide, yellowish ring at base (proportionally wider on VI); antennomeres VII-IX with narrow, yellowish ring at base; antennomere X yellowish on basal half, gradually brown toward apex; antennomere XI yellowish on basal third, gradually brown toward apex (with slightly distinct yellowish-brown ring near apex); femora dark reddish-brown with moderately distinct, wide, dark-brown ring about center of club; tibiae reddishbrown (more brownish on base), with wide, brown ring near middle; tarsi yellowish-brown except darkbrown claws. Part of grayish-white pubescence more yellowish depending on angle of light.

HEAD. Frons moderately coarsely, abundantly punctate; with grayish-white pubescence not obscuring integument; with one long, erect, yellowish seta close to lower eye lobes. Vertex moderately finely, abundantly punctate (punctures denser than on frons); with grayish pubescence not obscuring integument. Eyes surrounded by narrow band of yellowish pubescence. Tempora with punctures as on vertex on area closer to vertex, impunctate on remaining surface behind upper eye lobe, tumid, finely, sparsely punctate close to lower eye lobe; with grayish-white pubescence behind upper eye lobes and tumid area behind lower eye lobes (except yellowish band close to eye), glabrous on remaining surface behind lower eye lobes. Genae finely striate centrally; with sparse, grayish-white pubescence, gradually sparser toward apex; with some long, erect, yellowish setae ventrally. Antennal tubercles impunctate; with grayishwhite pubescence not obscuring integument. Coronal suture distinct from clypeus to prothoracic margin. Postclypeus very narrow, shiny, with a central longitudinal carina. Labrum concave, coplanar with anteclypeus on basal quarter, distinctly sloped on distal 3/4; finely, abundantly punctate; with long, erect, yellowish setae directed forward, mainly laterally. Mandibles with wide, sub-triangular depression from base to slightly after middle; with long, sparse, erect, yellowish setae on sub-triangular depression, glabrous toward apex. Distance between upper eye lobes 0.3 times length of scape; distance between lower eye lobes in frontal view 0.8 times length of scape. Antennae 1.75 times elytral length, reaching elytral apex at distal third of antennomere VIII; scape gradually enlarged on basal third (more abruptly at inner side); ventral side of scape, pedicel and antennomeres with erect, brownish setae ventrally, more abundant on III, gradually shorter, sparser toward distal segments; antennal formula (ratio) based on antennomere III: scape $=0.88$; pedicel $=0.15 ; \mathrm{IV}=1.67 ; \mathrm{V}=1.49 ; \mathrm{VI}=1.20 ; \mathrm{VII}=1.00 ; \mathrm{VIII}=0.84$; $\mathrm{IX}=0.75 ; \mathrm{X}=0.71 ; \mathrm{XI}=0.82$.

Thorax. Prothorax, excluding lateral tubercles, as long as wide; sides with small, conical tubercle at middle; surface moderately fine, abundantly punctate; with grayish-white pubescence not obscuring integument. Pronotum almost impunctate basally, centrally longitudinally carinate; remaining surface coarsely, abundantly, partially confluently punctate; surface with grayish-white pubescence, not obscuring integument, except on center of longitudinal carina with yellowish pubescence. Prosternum moderately finely, sparsely punctate; with grayish-white pubescence not obscuring integument. Mesosternum centrally finely, moderately abundant punctate, smooth laterally; with grayish-white pubescence more distinct and abundant laterally. Mesepisternum moderately coarsely, abundantly punctate; with slightly yellowish pubescence not obscuring integument. Metepisternum with slightly yellowish pubescence not obscuring integument. Metasternum moderately coarsely, sparsely punctate; with yellowish pubescence not obscuring integument. Scutellum with grayish-white pubescence, more yellowish laterally.

ELYTRA. Coarsely, abundantly punctate, distinctly sparser near suture on distal third and laterally on distal quarter; with several irregular, small areas with grayish pubescence distinctly contrasting with the 
general pubescence; apex obliquely sinuous, with outer angle forming distinct tooth and sutural angle rounded, slightly projected.

LEGS. Meso- and metatibiae with moderately short, erect, abundant, yellowish setae on distal third.

AвDOMEN. Ventrites impunctate; with grayish-white pubescence interspersed with long, erect, sparse setae (more abundant on distal half of ventrite $\mathrm{V}$ ); ventrite $\mathrm{V}$ slightly sulcate longitudinally at center on basal $3 / 4$, with apex truncate.

\section{Male}

Antennae longer, reaching elytral apex at base of distal third of antennomere VI. Apex of ventrite V slightly and widely emarginate.

\section{Variability}

Antennomere III dark reddish-brown on basal 3/4; antennomere X brownish only near apex; antennomere XI yellowish with slightly distinct brownish ring near apex; tarsomeres maculate with brown color; punctures on frons denser, similar to vertex; pronotum punctate basally; pronotal punctures not partially confluent.

\section{Remarks}

Nyctonympha flavipes was recorded from Peru and Brazil (Rondônia) by Martins \& Galileo (1989) and for Brazil (Maranhão) by Martins et al. (2011). However, as N. flavipes was mistakenly identified, we are formally excluding this species from the Peruvian and Brazilian fauna.

\section{Provisional key to species of Nyctonympha}

1. Dorsal and lateral longitudinal carinae on elytra distinct. Venezuela

N. costipennis (Lameere, 1893)

- Dorsal and lateral carinae on elytra feebly marked or absent ..............................

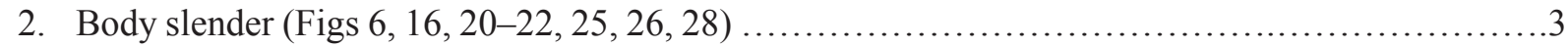

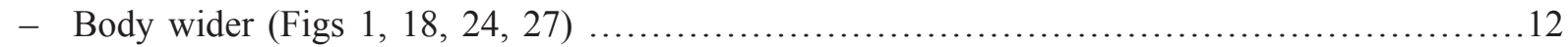

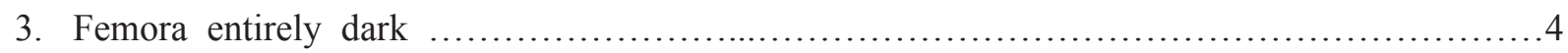

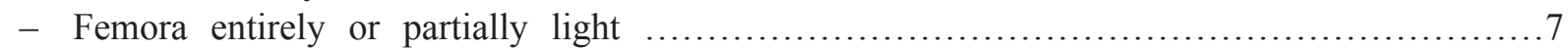

4. Distance between upper eye lobes distinctly wider than width of one lobe .................5

- Distance between upper eye lobes about equal to width of one lobe .......................6

5. Punctures on scape and femora distinctly contrasting with pubescence; mesepisternum punctate (Fig. 21). Colombia ........................................ boyacana Galileo \& Martins, 2008

- Punctures on scape and femora not distinctly contrasting with pubescence; mesepisternum smooth (Figs 5-8). Colombia N. antonkozlovi sp. nov.

6. Apex of sutural angle of the elytra projected. Colombia ...N. howdenarum Martins \& Galileo, 1992

- Apex of sutural angle of the elytra rounded (Fig. 16). Panama, Venezuela .N. annulata Aurivillius, 1900

7. Elytra coarsely punctate (punctures on basal half closer than diameter of one puncture) (Fig. 20). Ecuador, Bolivia N. flavipes Aurivillius, 1920

- Elytra moderately finely punctate (punctures on basal half farther apart than the diameter of one puncture) 


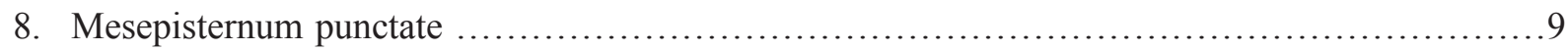

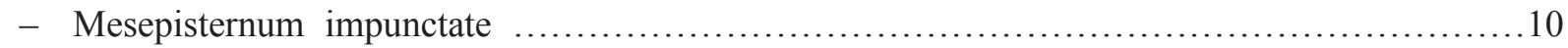

9. Scape reddish-brown (Fig. 28). Ecuador ....................... genieri Martins \& Galileo, 1992

- Scape dark-brown (Figs 22-23). Brazil (Rio de Janeiro), Bolivia (?)

N. carioca Galileo \& Martins, 2001

10. Tibiae with dark ring at middle. Peru, Bolivia ........................ annulipes (Belon, 1897)

- Tibiae not centrally ringed ..............................................................

11. Abdominal ventrites smooth (Fig. 25). French Guiana ......N. affinis Martins \& Galileo, 2008

- Abdominal ventrites punctate (Fig. 26). Argentina (Salta), Bolivia

N. punctata Martins \& Galileo, 1989

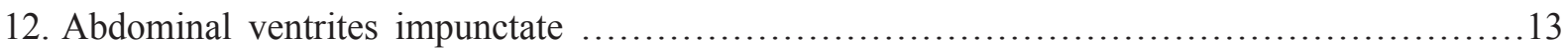

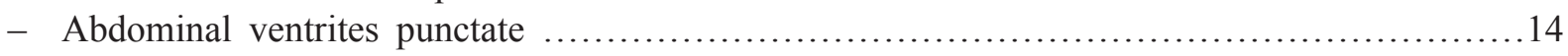

13. Mesepisternum punctate (Figs 17-19). Venezuela .................. carcharias (Lameere, 1893)

- Mesepisternum impunctate (Fig. 27). Trinidad and Tobago ........ taeniata Martins \& Galileo, 1992

14. Femora with punctures distinctly contrasting with pubescence (Fig. 24). Colombia

N. cribrata (Thomson, 1868)

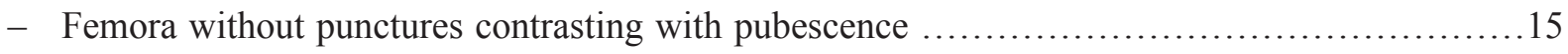

15. Body moderately wide; lateral tubercles of prothorax acute at apex; elytral apex strongly, obliquely truncate with outer angle forming long spine. Colombia, Bolivia

N. andersoni Martins \& Galileo, 1992

- Body notably wide; lateral tubercles of prothorax blunt at apex; elytral apex obliquely truncate with outer angle not forming long spine (Figs 1-4). Colombia

N. sinjaevi sp. nov.

\section{Discussion}

With the description of four new species herein, Nyctonympha now comprises 18 species distributed from Panama to the north of Argentina. Future examination of large series of specimens may provide a better understanding of the species, allowing improvement of the key and a better understanding of the true geographical distribution of each species. We hope to locate the holotype of Hebestola costipennis, to confirm or not its exclusion from Nyctonympha. The discovery of these new species suggests that a huge diversity in Cerambycidae remains to be described.

\section{Acknowledgments}

The authors would like to thank Anton Olegovich Kozlov for sending two of the species described in this work, Norma Giambarresi Ganho (DZUP) for the photos of the types of Nyctonympha taken by the late priest Jesus Santiago Moure, Larry G. Bezark for reviewing the English text and Alain Drumont (IRSNB) for the information about the holotype of Hebestola costipennis.

\section{References}

Aurivillius C. 1900. Verzeichnis der von Dr. F. Meinert im Jahre 1891 in Venezuela gesammelten Cerambyciden. Öfversigt af kongliga Vetenskaps-Akademiens Förhandlingar 57: 409-421. Available from http://biodiversitylibrary.org/page/32289583 [accessed 16 May 2017].

Aurivillius C. 1920. Neue oder wenig bekannte Coleoptera Longicornia. 17. Arkiv för Zoologi 13 (9): 361-403. Available from http://biodiversitylibrary.org/page/6397028 [accessed 16 May 2017]. 

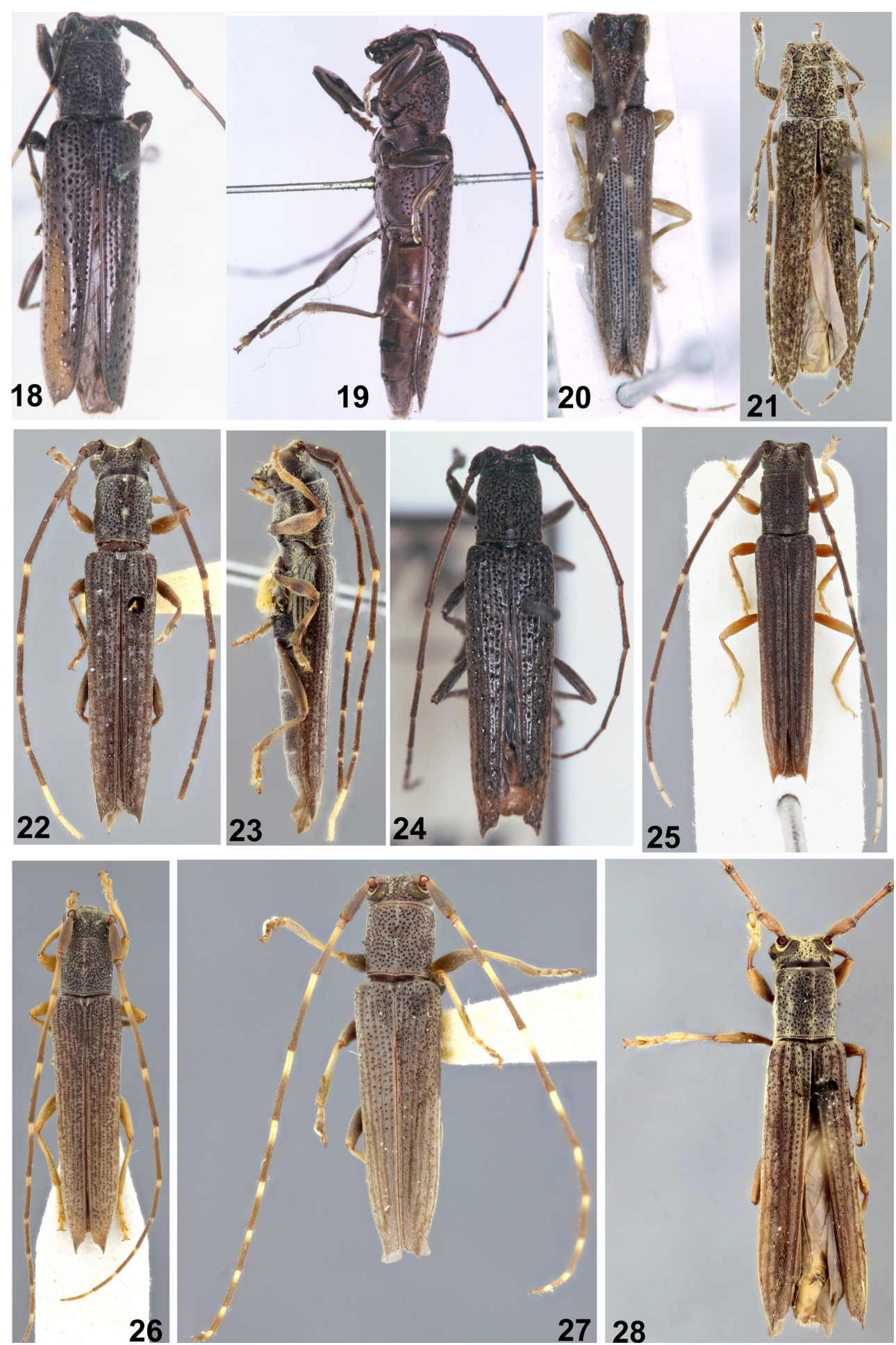

Figs 18-28. - 18-19. Nyctonympha glauca Aurivillius, 1900, holotype. 18. Dorsal habitus. 19. Lateral habitus. - 20. Nyctonympha flavipes Aurivillius, 1920, holotype, dorsal habitus. - 21. Nyctonympha boyacana Martins \& Galileo, 2008, paratype, ㅇ. - 22-23. Nyctonympha carioca (Galileo \& Martins, 2001), holotype. 22. Dorsal habitus. 23. Lateral habitus. - 24. Nyctonympha cribrata (Thomson, 1868), holotype, dorsal habitus. - 25. Nyctonympha affinis Martins \& Galileo, 2008, holotype, + dorsal habitus. - 26. Nyctonympha punctata Martins \& Galileo, 1989, holotype, §̂, dorsal habitus. 27. Nyctonympha taeniata Martins \& Galileo, 1992, paratype, + , dorsal habitus. - 28. Nyctonympha genieri Martins \& Galileo, 1992, paratype,, , dorsal habitus. 
Belon P.M. 1897. Description d'un longicorne nouveau du genre Hebestola (Col.). Bulletin de la Société Entomologique de France 1897: 186-188.

Bezark L.G. 2016. A Photographic Catalog of the Cerambycidae of the New World. Available from https://apps2.cdfa.ca.gov/publicApps/plant/bycidDB/wsearch.asp?w=n [accessed Aug. 2016].

Galileo M.H.M. \& Martins U.R. 2001. Novas espécies de Lamiinae (Coleoptera, Cerambycidae) neotropicais. Iheringia, Zoologia 90: 59-70. https://doi.org/10.1590/S0073-47212001000100007

Galileo M.H.M. \& Martins U.R. 2008. Espécies novas de Calliini e Falsamblesthiini (Coleoptera, Cerambycidae, Lamiinae) da Região Neotropical. Revista Brasileira de Entomologia 52 (1): 32-35. https://doi.org/10.1590/S0085-56262008000100006

Lameere A.A. 1893. Voyage de M.E. Simon au Venezuela (Decembre 1887-Avril 1888). 23e Mémoire. Longicornes. Annales de la Société Entomologique de France 62: 273-280.

Martins U.R. \& Galileo M.H.M. 1989. Sobre Falsamblesthiini (Coleoptera, Cerambycidae, Lamiinae). III. Subsídios para uma revisão. Revista Brasileira de Entomologia 33 (1): 119-134.

Martins U.R. \& Galileo M.H.M. 1992. Neotropical Cerambycidae (Coleoptera) primarily in the Canadian Museum of Nature, Ottawa. I. Falsamblesthiini (Lamiinae). Insecta Mundi 6 (2): 101-108.

Martins U.R. \& Galileo M.H.M. 2008. Novos Cerambycidae (Coleoptera) da coleção Odette Morvan, Guiana Francesa. II. Papéis Avulsos de Zoologia 48 (8): 55-59. https://doi.org/10.1590/S0031$\underline{10492008000800001}$

Martins U.R., Galileo M.H.M. \& Limeira-de-Oliveira F. 2011. Cerambycidae (Coleoptera) do Estado de Maranhão, Brasil III. Papéis Avulsos de Zoologia 51 (18): 275-293.

Monné M.A. 2016. Catalogue of the Cerambycidae (Coleoptera) of the Neotropical region. Part II. Subfamily Lamiinae. Available from http://cerambyxcat.com/ [accessed Aug. 2016].

Monné M.A. \& Hovore F.T. 2006. Checklist of the Cerambycidae, or Longhorned Wood-Boring Beetles, of the Western Hemisphere. Bio Quip Publications, Rancho Dominguez.

Thomson J. 1868. Matériaux pour servir à une révision des desmiphorites (Lamites, cérambycides, coléoptères). Physis recueil d' Histoire naturelle 2 (6): 101-146.

Manuscript received: 13 September 2016

Manuscript accepted: 21 October 2016

Published on: 27 June 2017

Topic editor: Gavin Broad

Desk editor: Kristiaan Hoedemakers

Printed versions of all papers are also deposited in the libraries of the institutes that are members of the EJT consortium: Muséum national d'Histoire naturelle, Paris, France; Botanic Garden Meise, Belgium; Royal Museum for Central Africa, Tervuren, Belgium; Natural History Museum, London, United Kingdom; Royal Belgian Institute of Natural Sciences, Brussels, Belgium; Natural History Museum of Denmark, Copenhagen, Denmark; Naturalis Biodiversity Center, Leiden, the Netherlands; Museo Nacional de Ciencias Naturales-CSIC, Madrid, Spain; Real Jardín Botánico de Madrid CSIC, Spain. 